\title{
(CON)TATO E DIÁLOGO NA EDUCAÇÃO SEXUAL·
}

\author{
Maria do Amparo Rocha Caridade ${ }^{1}$ \\ (CON)TACT AND DIALOGUE IN SEX EDUCATION
}

Resumo: Neste artigo reflete-se sobre a importância da educação sexual na família. Pontuando que todo o início das interações afetivas e de contato entre os pais e o bebê, são as primeiras formas de educação sexual.

Palavras-chave: Educação sexual. Afeto. Contato.

\begin{abstract}
This article dwells on the importance of sex education in the family. We should highlight that beginning of affective interactions and contact between parents and baby, are the first forms of sex education.
\end{abstract}

Keywords: Sex education. Affection. Contact.

Pensar a educação sexual visualizando a inteireza da pessoa, é remeter a questão à anterioridade do nascimento, quando o casal opta pela criança. Somos seres do desejo, e desejar ter ou não ter um filho marca profundamente às relações entre o pai, a mãe e a criança. O bebê desejado, benvindo ao mundo, certamente é tocado, cuidado e amado sem barreiras. Estrutura-se aí a dimensão primeira da sexualidade, numa relação epidérmica e experiencial, anterior à palavra não-conceitual.

O (con)tato corporal é a linguagem densa com a qual se torna possível a comunicação com o bebê. O alimentar, acariciar, embalar, limpar, cuidar ou descuidar, são aignos dessa comunicação primeira.

Através destes gestos, o bebê apreende o mundo, as pessoas e as relações. O adulto em contato com a criança é veiculador de informações plurais e possibilitador da experiência do corpo como desejável e prazerozo, do outro como terno e confiável, do mundo como agradável ou ameaçador. É a primeira leitura do ser humano que vem ao mundo em estado de nudez, e que vai inscrevendo no corpo a sua história, através da vestimenta que o universo de relações lhe tece.

No convívio com o bebê, a abstração, o raciocínio, a lógica cedem lugar ao toque, ao

- Artigo publicado na Revista Sexus - Estudo Multidisciplinar da Sexualidade Humana, 2(2), 1990, p. 12-3. Publicação do NUDES - Núcleo de Sexologia do Rio de Janeiro. Rio de Janeiro: Europa Gráfica e Editora.

${ }^{1}$ Psicóloga clínica. Mestre em Antropologia. Prof. Adjunta da Universidade Católica de Pernanbuco. Membro fundador do ISES - Instituto de Sexologia e Educação Sexual, em Recife. 
(con)tato, que marcam a etapa primordial da educação sexual que a vida possibilita. É o registro primitivo da sexualidade que se presentifica em cada corpo humano, arqueologicamente, côo pré-história. Nenhum projeto de educação sexual posterior pode ignorar estes alicerces. Conceitos formulam-se e reformulam-se; estudamos, conhecemos, aprendemos, mas a vivência da sexualidade é marcada por estes registros inconscientes dos primeiros contatos.

A casa é a primeira escola de educação sexual, o lugar da maternagem e da paternagem, englobando todos os cuidados que os pais dispensam à criança.

Hildegger (apud MAY, 1973) considera o cuidado como o fenômeno básico constitutivo da existência humana. É ontológico porque faz do homem um homem. O cuidado é a expressão concreta do amor, é um estado no qual algo tem importância. Esta dimensão registra para a criança sua cndição de "ser desejável." Poderá a criança mal cuidada, mal-amada, mal-tocada, sentir-se desejável?

A vivência prazerosa e expressiva da sexualidade dos pais é a mais autênctica e eficiente educação sexual. Entretanto, a grande maioria pertence a uma geração que silenciou a própria sexualidade como forma de negá-la, de reprimi-la, o que dificultou o desenvolvimento de atitudes livres e tranparentes frente à própria vivência do sexo. Somos fruto da "Scientia sexualis" e não da "Ärs erótica" (FOUCAULT, 1974). O saldo disto é a inquietação e insegurança face à sexualidade vivida e questionada pelos filhos.

A corporeidade, essa dimensão dionísica da vida, vem sendo progressivamente resgatada. Sexo-pecado, corpo inferior, são gestos e direitos, termos questionados nos concetos e discursos da modernidade. Isto vem possibilitando maior desnudamento do casal para o próprio ato de amar e gerar um filho. Homens e mulheres buscam igualdade no desejo e na conquista do prazer, tentam a mesma linguagem, exigem-se democraticamente dividem o comando no gestual dos corpos entrelaçados.

Há quem veja nessa integração sexual entre o homem e a mulher um saldo muito positivo, como o surgimento de uma juventude mais bonita e indiscutivelmente "melhor fabricada". Persistem receios de que a fala aberta sobre sexo, exacerbe o desejo de crianças e adolescentes, ou que o (con)tato com o nu em família antecipe fantasias eróticas. A prática mostra, pelo contrário, que um contexto de abertura e largueza de informações, reduz a tensão que o sexo provoca, possibilitando inclusive o adiamento do exercício da genitalidade, para 
um momento de maior fruição. Estudos revelam que o indivíduo educado num ambiente negador da vida e do sexo, adquire uma ansiedade frente ao prazer que torna doentia sua forma de viver e se expressar (NAZÁRIO, 1987). Nenhuma defesa humana é mais absurda e perigosa que a negação. Estudos transculturais também têm revelado que crianças educadas com cantato físico e permissividade sexual resultam em índices reduzidos de violência adult (CONSTANTINE, MARTINSON, 1984). Talvez possamos analisar por este ângulo o alto índice de violência sexual que marca os dias atuais.

O diálogo é a ferramenta básica no processo de educar para a sexualidade. Há crianças que perguntam muito, outras nada interrogam e outras ainda precisam de um ambiente encorajador para atreverem-se a levantar algumas questões. Todas têm direito às respostas que buscam. Todas devem ser consideradas "seres sexuais," ter acesso a material informativo sobre a sexualidade e dispor de bibliografia adequada à idade em que se encontram. O diálogo é o exercício natural para o desenvolvimento da relação adulta, para o encontro entre pessoas.

A escola precisa continuar o trabalho de educação sexual repensando dimensões esquecidas, visões distorcidas ou negadas da sexualidade sem, contudo substituir a família. A criança já não chega à escola com o corpo transparente, em estado de nudez, mas com diversas inscrições acerca do sexo. A interação família-escola torna-se fundamental para que ela não se torne alvo da duplicidade de discursos e de atitudes, em seu processo educacional.

A tarefa da educação sexual torna-se emocionalmente custosa também aos professores, igualmente pertencenes a esta cultura marcada pela "Scientia sexualis", e que nem sempre sentem-se disponíveis, tranqüilos e maduros frente à própria sexualidade. Mesmo assim, quase sempre a escola torna-se o espaço mais aberto onde os adolescentes fazem seus questionamentos. Nos debates sobre a sexualidade tenho observado que os jovens fazem perguntas que os pais e mesmo os mestres não se atrevem a fazer. São gerações diferentes sinalizando as relações de fechamento-abertura frente ao discurso do sexo.

É função da educação sexual suscitar, estimular a troca e o encontro entre as pessoas. A experiência sexual básica é de (con)tato e troca. O impulso natural do organismo enquanto sistema aberto é a troca com o ambiente. Max Pagès vê no desejo, no prazer e na sociabilidade, um todo dado e indissociável. A partilha do prazer é a base da própria experiência social e possibilita a descoberta de si e dos outros. É a impossibilidade de partilhar que está na origem das formas possessivas, e a possessividade detém as mudanças (PAGÈS, s/d). 
Troca e encontro é que possibilitarão as mudanças nas relações sociais. Uma resisão dos padrões machistas, e o estabelecimento da igualdade e liberdade para ambos os sexos torna-se imprescindível. Fora disso, tudo o que for alterado levará a novas formas de repressão. A possibilidade da partilha amorosa está na igualdade, na relação EU-TU (BURGER, 1979). Que não invertamos os termos da relação a ponto de amarmos as coisas e possuirmos as pessoas.

\section{Referências bibliográficas:}

BURGER, M. A relação Eu e Tu. São Paulo: Editora Cortez e Moraes, 1979.

CONSTANTINE, L.; MARTINSON, F. Sexualidade Infantil. São Paulo: Editora Roca, 1984.

FOUCAUlT, M. História da Sexualidade. A vontade de saber. Rio de Janeiro: Editora Graal, 1974.

MAY, R. Eros e Repressão. Petrópolis: Editora Vozes, 1973.

NAZÁRIO, L. Sexo. A alienação do Desejo. São Paulo: Editora Brasiliense, 1987.

PAGÈS, M. O Trabalho Amoroso. Lisboa: Vega Universidade, s/d. 